\title{
Sensitivitas dan Spesifisitas Cystatin C dan Kreatinin Serum dalam Mendiagnosis Cedera Ginjal Akut pada Pasien Sepsis yang Dirawat di Ruang Rawat Intensif RSUP H. Adam Malik Medan
}

\author{
Hasanul Arifin, Heru Kurniawan \\ Departemen/SMF Anestesiologi dan Terapi Intensif \\ Fakultas Kedokteran Universitas Sumatera Utara/Rumah Sakit Umum Pusat H. Adam Malik Medan
}

\begin{abstract}
Abstrak
Kreatinin serum memiliki banyak keterbatasan dalam mendiagnosis cedera ginjal akut (CGA) terutama dalam ruang lingkup unit perawatan intensif sehingga kurang sensitif untuk menggambarkan tingkat disfungsi ginjal pada pasien sakit kritis. Dari sekian banyak penanda biologis baru yang tersedia, terdapat 4 penanda biologis yang saat ini secara luas digunakan para klinisi di seluruh dunia untuk mendeteksi CGA, antara lain neutrophil gelatinase-associated lipocalin (NGAL), cystatin C, KIM-1, dan interleukin-18. Tujuan penelitian ini adalah mengetahui sensitivitas dan spesifisitas cystatin $\mathrm{C}$ dan kreatinin serum dalam mendiagnosis cedera ginjal akut pada pasien sepsis yang dirawat di ruang rawat intensif. Jenis penelitian ini adalah uji diagnostik dengan jumlah sampel 24 pasien dan dikerjakan di ruang rawat intensif Rumah Sakit H. Adam Malik (RSHAM) periode Februari-Maret 2014. Populasi dalam penelitian ini adalah semua pasien dewasa dengan sepsis, sepsis berat, dan syok sepsis di ruang rawat intensif. Uji statistik dilakukan dengan metode receiving operator characteristics (ROC) melalui perangkat lunak SPSS 17. Hasil penelitian ini menunjukkan bahwa cystatin $\mathrm{C}$ serum lebih superior dibanding dengan kreatinin serum dalam mendeteksi CGA pada pasien sepsis di ruang rawat intensif. Cystatin C memiliki sensitivitas, nilai prediksi positif, nilai prediksi negatif, dan area under curve-receiving operator characteristics (AUC-ROC) yang lebih tinggi dibanding dengan kreatinin serum. Namun, dari nilai spesifisitas dijumpai nilai yang sama pada kedua penanda biologis. Simpulan, cystatin C dapat dijadikan penanda biologis alternatif untuk deteksi CGA pada pasien sepsis di RRI (Ruang Rawat Intensif) dengan nilai diagnostik yang lebih baik.
\end{abstract}

Kata kunci: Cedera ginjal akut, cystatin C serum, kreatinin serum

\section{Sensitivity and Specificity of Serum Cystatin C and Creatinine for Diagnosing Acute Kidney Injury in Sepsis Patients Treated in Intensive Care Unit at H. Adam Malik Hospital Medan}

\begin{abstract}
Serum creatinine has many limitations when being used to diagnose acute kidney injury (AKI), especially in the scope of intensive care unit due to its low sensitivity to depict the kidney dysfunctional level of criticallyill patients. Out of numerous new available biological markers, four biological markers are widely used all over the world to detect AKI, e.g. neutrophil gelatinase-associated lipocalin (NGAL), cystatin C, KIM-1, and interleukin-18. The purpose of this study was to determine the sensitivity and specificity of serum cystatin $\mathrm{C}$ and creatinine in establishing the diagnosis of acute kidney injury in sepsis patients treated in intensive care room. This study was a diagnostic test to 24 patients and conducted in intensive care room of $\mathrm{H}$. Adam Malik Hospital during the period of February-March 2014. Population in this study is all adult patients with sepsis, severe sepsis, and septic shock in the intensive care room. A statistical test was conducted using receiving operator characteristics (ROC) method using SPSS 17 software. The result of this study showed that serum cystatin $\mathrm{C}$ was more superior than serum creatinine in detecting acute kidney injury in sepsis patients treated in intensive care room. In this study, cystatin C had higher sensitivity, positive prediction score, negative prediction score, and area under curve-receiving operator characteristics (AUC-ROC) than serum creatinine. As of specificity, there was no significant difference between these two biological markers. In conclusion, cystatin C can be an alternative biological marker to detect AKI in sepsis patients treated in intensive care room with a better diagnostic value.
\end{abstract}

Key words: Acute kidney injury, serum creatinine, serum cystatin C

Korespondensi: Hasanul Arifin, dr., SpAn-KAP-KIC, Departemen Anestesiologi dan Terapi Intensif Fakultas kedokteran Universitas Sumatera Utara/Rumah Sakit Umum Pusat Haji Adam Malik Medan, Jl. Bunga Lau Medan 20136, Tlpn 0618362080, Mobile 0811614633, Email rakajati84@yahoo.co.id 


\section{Pendahuluan}

Kasus cedera ginjal akut (CGA) sering dijumpai di ruang rawat intensif (RRI). Insidensi CGA akhir-akhir ini meningkat dan berhubungan dengan peningkatan yang substansial dalam morbiditas dan mortalitas. Cedera ginjal akut terjadi pada sekitar 7\% pasien rawat inap dan $36 \%$ sampai dengan $67 \%$ pada pasien kritis bergantung pada definisi yang dipergunakan. Berdasarkan penelitian pada lebih dari 75.000 orang dewasa dengan sakit kritis, CGA yang lebih parah terjadi pada sekitar $4 \%$ sampai $25 \%$ pasien yang masuk RRI dengan sepsis sebagai penyebab utama. ${ }^{1}$

Pada penelitian multisenter di beberapa RRI yang melibatkan hampir 30 ribu pasien menyatakan kejadian CGA yang berhubungan dengan kasus sepsis berat dan juga syok sepsis memberikan kontribusi 50\% kasus CGA di RRI. ${ }^{2}$ Berdasarkan hasil survei yang dilakukan di Italia melalui pengumpulan data webbased, hampir dua pertiga kasus CGA didiagnosis dalam waktu 24 jam masuk RRI dan sekitar 5-6\% pasien RRI dengan CGA memerlukan terapi pengganti ginjal (TPG). Pada penelitin lain dinyatakan bahwa sekitar $12 \%$ pasien CGA diobati dengan TPG di RRI.1,3 Terapi pengganti ginjal (TPG) dimulai rata-rata pada hari kedua setelah masuk RRI. Sebanyak 60\% pasien CGA mengalami pemulihan fungsi ginjal lengkap, $13,5 \%$ mengalami pemulihan ginjal parsial, sementara $30 \%$ tidak mengalami pemulihan fungsi ginjal sampai saat kematian atau saat keluar RRI setelah pengobatan. ${ }^{3}$

Saat ini dapat dijumpai lebih dari 35 definisi CGA dalam berbagai literatur. Kelompok the Acute Dialysis Quality Initiative (ADQI) telah mengembangkan sistem untuk menentukan diagnosis serta klasifikasi berbagai gangguan akut fungsi ginjal yang dirangkum dalam bentuk akronim risk, injury, failure, loss, endstage renal disease (RIFLE) untuk memberikan gambaran tingkat keparahan gangguan: risk, injury, failure, loss, dan end-stage renal disease (ESRD). Tingkat keparahan didefinisikan atas dasar perubahan dalam kreatinin serum atau produksi urin. Klasifikasi yanglebih baru untuk CGA berdasarkan pada sistem RIFLE telah diusulkan oleh Acute Kidney Injury Network (AKIN). Sistem penentuan baru ini berbeda dari klasifikasi RIFLE dalam hal mengurangi kebutuhan untuk kreatinin awal dan membagi tingkat keparahan dalam 3 bagian., ${ }^{4,5}$

Kedua klasifikasi CGA yang masih banyak digunakan oleh para klinisi tersebut masih menggunakan kriteria kreatinin serta output urin untuk memberi gambaran derajat ringan berat disfungsi ginjal. Sayangnya, kreatinin adalah indikator yang kurang dapat diandalkan selama perubahan akut fungsi ginjal. Pertama, konsentrasi kreatinin serum tidak mungkin berubah sampai sekitar $50 \%$ dari fungsi ginjal yang telah hilang. Kedua, kreatinin serum tidak akurat menggambarkan fungsi ginjal sampai keadaan stabil telah tercapai yang mungkin membutuhkan beberapa hari. Penggunaan kreatinin serum untuk memperkirakan laju filtrasi glomerulus (LFG) sangatlah terbatas, hal ini dikarenakan minimnya kondisi steady state pada pasien sakit kritis. Saat ini terdapat beberapa penanda/marker biologis yang telah digunakan untuk deteksi awal CGA seperti cystatin $\mathrm{C}$, neutrophil gelatinase associated lipocalin (NGAL), KIM-1, interleukin-18, dan penanda lainnya. Penanda biologis ini memiliki kelebihan dan kekurangan masing-masing. ${ }^{6}$

Pada penelitian prospektif dengan cara mengambil sampel urin dan serum serial dari 71 anak yang menjalani cardiopulmonary bypass (CPB) untuk koreksi bedah penyakit jantung bawaan, dua puluh anak berkembang menjadi kasus CGA yang didefinisikan sebagai peningkatan $50 \%$ kreatinin serum. Kadar NGAL urin pada 2 jam menjalani CPB hampir secara sempurna memprediksi pasien yang akan berkembang menjadi CGA. ${ }^{7}$ Penelitian lain pada 103 orang dewasa yang menjalani cardiopulmonary bypass (CPB), ternyata CGA berkembang $31 \%$ pada mereka yang kadar KIM-1 urinnya meningkat sekitar 40\% setelah 2 jam operasi dan $100 \%$ pada waktu jam ke$24 .^{8}$ Dengan demikian, KIM-1 merupakan kandidat yang menjanjikan untuk dimasukkan dalam penanda biologis CGA urin. Penelitian lain menunjukkan bahwa IL-18 urin secara signifikan mengalami upregulation hingga 48 jam sebelum peningkatan kreatinin serum 
pada pasien sindrom gangguan pernapasan akut yang berkembang menjadi CGA. ${ }^{9}$

Cystatin C termasuk superfamili cystatin yang merupakan inhibitor protease sistein. Kebanyakan hasil penelitian yang dilakukan menunjukkan bahwa cystatin $\mathrm{C}$ dapat menjadi prediktor laju filtrasi glomerulus yang lebih baik bila dibanding dengan kreatinin. ${ }^{10}$ Suatu penelitian pada tahun 2004 terhadap 85 pasien yang berisiko tinggi untuk berkembang menjadi CGA dilakukan dengan menggunakan kriteria RIFLE. Penelitian ini menunjukkan cystatin $\mathrm{C}$ serum adalah penanda biologis yang bermanfaat pada CGA dan dapat mendeteksi CGA 1-2 hari lebih cepat daripada kreatinin serum. ${ }^{11}$ Suatupenelitian pada 53 pasien sirosis hepatis yang bertujuan mengetahui peran cystatin C serum sebagai faktor prognostik untuk CGA, diperoleh bahwa cystatin C serum dan juga kreatinin serum merupakan faktor prediktif untuk CGA dengan akurasi diagnostik 0,735 untuk cystatin C serum dan 0,698 untuk kreatinin serum. Pada simpulan didapatkan bahwa akurasi dalam memprediksi CGA dan mortalitas jangka pendek adalah lebih tinggi pada kadar cystatin $\mathrm{C}$ serum, yaitu $>1,23 \mathrm{mg} / \mathrm{L}$ daripada kreatinin serum pada pasien sirosis hepatis. ${ }^{12}$

Suatu penelitian pada 50 pasien di RRI yang memiliki risiko tinggi berkembang menjadi CGA, diperoleh bahwa cystatin C serum secara diagnostik lebih superior dibanding dengan kreatinin serum AUC untuk kreatinin serum 0,694 dengan IK 95\% berbanding AUC untuk cystatin C serum 0,927 dengan IK 95\%. ${ }^{13}$ Hasil penelitian yang berbeda ditunjukkan pada 151 pasien di RRI yang dinyatakan bahwa baik serum maupun cystatin C urin merupakan penanda biologis yang buruk untuk prediksi CGA serta kebutuhan TPG. ${ }^{14}$

Spahillari dkk..$^{15}$ dalam hasil penelitiannya terhadap 1.150 pasien pascaoperasi jantung, menyatakan bahwa kadar cystatin $\mathrm{C}$ serum kurang sensitif daripada kadar kreatinin serum dalam mendeteksi CGA pascaoperasi jantung. Penelitian yang dilakukan Slort dkk. ${ }^{16}$ pada 24 pasien yang menjalani transplantasi ginjal pada anak menyimpulkan bahwa cystatin $\mathrm{C}$ serum tidak lebih superior dibanding dengan kreatinin serum untuk mendeteksi disfungsi allograft akut. ${ }^{16}$

Masih belum begitu banyak penelitian yang membandingkan penanda cystatin $\mathrm{C}$ serum dengan kreatinin serum dalam mendeteksi CGA yang disebabkan oleh sepsis. Penelitianpenelitian sebelumnya dilakukan lebih banyak pada pasien dengan penyebab CGA lainnya seperti pada pascaoperasi jantung, obat dan zat kontras, pascatransplantasi ginjal, sirosis hepatis, dan lain-lain. Selain itu, keadaan sepsis dapat menurunkan produksi kreatinin sehingga interpretasi nilai kreatinin semakin terbatas penggunaannya untuk deteksi dini CGA. ${ }^{17}$ Berdasarkan hal itu peneliti tertarik melakukan penelitian yang bertujuan membandingkan sensitivitas dan spesifisitas cystatin C serum dengan kreatinin serum dalam mendiagnosis CGA pada pasien sepsis, sepsis berat, dan syok sepsis di RRI Rumah Sakit H. Adam Malik (RSHAM) Medan.

\section{Subjek dan Metode}

Penelitian ini merupakan uji diagnostik yang menggunakan desain potong lintang (cross sectional). Populasi penelitian adalah semua pasien dewasa dengan sepsis, sepsis berat, dan syok sepsis di ruang rawat intensif periode Februari sampai dengan Maret 2014.

Kriteria inklusi penelitian ini adalah pasien berusia 18-65 tahun. Kriteria eksklusi adalah pasien dengan penyakit tiroid, pasien yang sedang mendapatkan terapi kortikosteroid, zat-zat nefrotoksik, cimetidin dan trimetoprim, pascaoperasi jantung, serta pasien dengan penyakit sirosis hepatis. Kriteria putus uji pada pasien ini adalah pasien meninggal sebelum 24 jam perawatan. Untuk menentukan besar sampel dilakukan perhitungan sesuai dengan penelitian diagnostik dengan keluaran area under curve (AUC) sehingga didapatkan besar sampel adalah 24 orang.

Pasien yang menjadi sampel penelitian paling cepat 2 jam setelah masuk ruang rawat intensif dilakukan pengumpulan urin dengan menampung setiap volume urin dalam jerigen penampung urin selama 24 jam ke depan. Pasien sepsis berat dan syok sepsis sesuai 


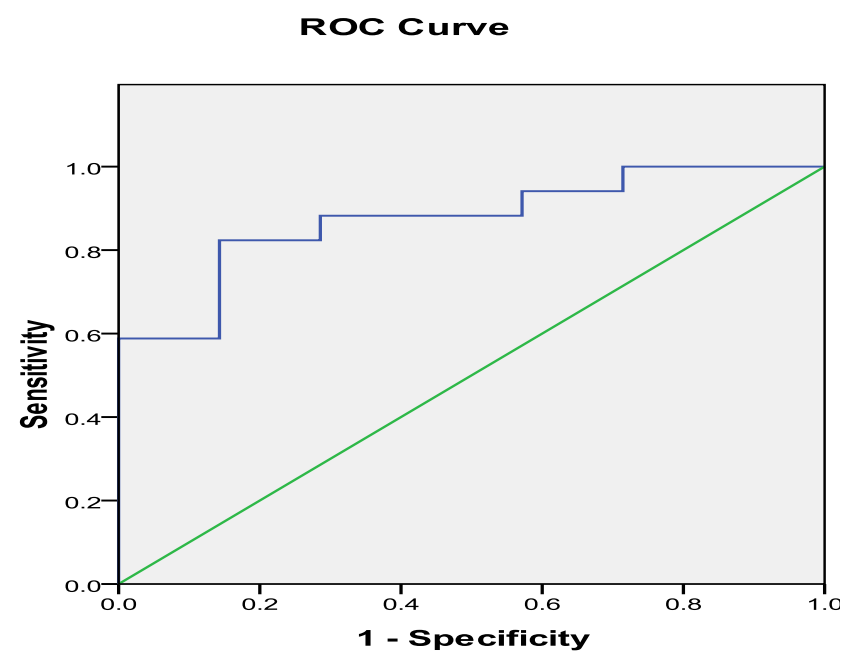

\section{Gambar 1 Kurva ROC Cystatin C Serum terhadap CGA}

rekomendasi Surviving Sepsis Campaign (SSC) 2012 dilakukan optimalisasi sesuai dengan International Guidelines for Management of Severe Sepsis and Septic Shock. Pada keesokan harinya setelah pengumpulan urin selama 24 jam dilakukan pengambilan sampel darah untuk pemeriksaan kreatinin dan cystatin C serum. Dilakukan juga pemeriksaan kreatinin dari urin yang telah dikumpulkan 24 jam untuk kemudian mengukur laju filtrasi glomerulus
(LFG) dengan menghitung klirens kreatinin 24 jam urin yang disesuaikan dengan body surface area pasien. Pemeriksaan kreatinin serum dan klirens kreatinin 24 jam urin dilakukan di laboratorium RSHAM, sedangkan pemeriksaan cystatin C serum dilakukan di laboratorium Prodia Medan. Kedua laboratorium ini telah diakreditasi oleh Badan Akreditasi Nasional. Pengambilan sampel darah dilakukan oleh tenaga analis laboratorium.

\section{Tabel 1 Karakteristik Responden Penelitian}

\section{Karakteristik Responden}

Usia, rata-rata (SD), tahun

Jenis kelamin, $\mathrm{n}$

Laki-laki

Perempuan

BSA $\left(\mathrm{kg} / \mathrm{m}^{2}\right)$

Jenis sepsis, $\mathrm{n}$

Sepsis

Sepsis berat

Syok sepsis

Kreatinin serum, rata-rata (SD)

Cystatin C serum, rata-rata (SD)

Creatinine $\mathrm{Cl}$ urin 24 jam, rata-rata (SD)

\section{$n=24$}

$42,96(15,81)$

$$
14
$$

1,65

11

12

1

$1,53(1,13)$

$1,71(1,1)$

$66,33(37,77)$ 


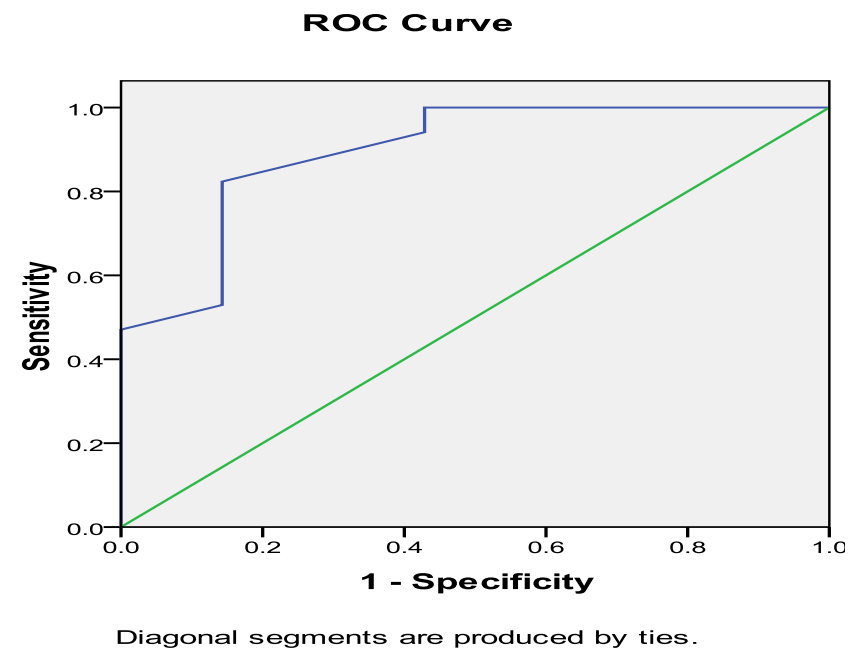

Gambar 2 Kurva ROC Kreatinin Serum terhadap CGA

\section{Hasil}

Penelitian diikuti oleh 24 pasien dengan usia rata-rata 42,96 tahun ( $\mathrm{SD}=15,81$ tahun) dan $58,3 \%$ responden adalah laki-laki. Nilai BSA rata-rata responden penelitian ini adalah 1,65 $(\mathrm{SD}=0,1)$. Sebanyak 12 dari 24 responden merupakan pasien sepsis berat dengan kadar kreatinin serum rata-rata $1,53 \mathrm{mg} / \mathrm{dL}(\mathrm{SD}=1,13$ $\mathrm{mg} / \mathrm{dL}$ ), kadar cystatin $\mathrm{C}$ serum rata-rata 1,71 $\mathrm{mg} / \mathrm{dL}(\mathrm{SD}=1,1 \mathrm{mg} / \mathrm{dL})$, dan kadar kreatinin $\mathrm{Cl}$ urin rata-rata $66,33 \mathrm{mg} / \mathrm{dL}(\mathrm{SD}=37,77 \mathrm{mg} /$ dL). Dari 24 pasien yang menjalani penelitian terdapat 17 pasien mengalami CGA, sedangkan sisanya 7 pasien tidak mengalami CGA.

Nilai sensitivitas dan spesifisitas cystatin C terhadap CGA dengan menggunakan cut-off 1,0 $\mathrm{mg} /$ Ladalah 82,35\% dan 85,71\%. Nilai prediksi positif dan prediksi negatif adalah 93,33\% dan $66,67 \%$, sedangkan rasio kemungkinan positif 5,76 dan rasio kemungkinan negatif 0,21. Cystatin $\mathrm{C}$ serum dalam studi ini mempunyai kemampuan mendeteksi seorang penderita akan mengalami cedera ginjal akut atau tidak. Dari hasil analisis menggunakan kurva ROC diperoleh bahwa area di bawah kurva (AUC) ROC adalah 0,874 (IK 95\% kreatinin: 69,2$100 \%$; $\mathrm{p}=0,005$ ).

Berdasarkan pada kurva sensitivitas dan spesifisitas, nilai cut-off untuk Cystatin C serum adalah 1,03 mg/L. Dengan menggunakan cutoff point $1,03 \mathrm{mg} / \mathrm{L}$ maka didapatkan nilai sensitivitas cystatin C serum adalah $82,4 \%$ dan spesifisitas $85,7 \%$. Nilai prediksi positif (PPV) cystatin C serum sebesar 93,3\% dan nilai prediksi negatif (NPV) 66,7\%, sedangkan rasio kemungkinan positif 5,76 dan rasio kemungkinan negatif 0,21 .

Nilai sensitivitas dan spesifisitas kreatinin serum terhadap CGA dengan menggunakan nilai cut-off $1,3 \mathrm{mg} / \mathrm{L}$ adalah $52,9 \%$ serta $85,7 \%$. Nilai prediksi positif dan nilai prediksi negatif adalah $90 \%$ dan $42,9 \%$, sedangkan rasio kemungkinan positif adalah 3,7 dan rasio

Tabel 2 Sensitivitas, Spesifisitas, Nilai Prediksi Positif (NPP), Nilai Prediksi Negatif (NPN), Rasio Kemungkinan Positif (RKP), dan Rasio Kemungkinan Negatif (RKN) dari Cystatin C Serum (COP 1,03 mg/L) terhadap CGA

\begin{tabular}{|c|c|c|c|c|c|c|c|c|c|}
\hline & & \multicolumn{2}{|c|}{ CGA } & \multirow{2}{*}{ Sensitivitas } & \multirow{2}{*}{ Spesifisitas } & \multirow{2}{*}{ NPP } & \multirow{2}{*}{ NPN } & \multirow{2}{*}{ RKP } & \multirow{2}{*}{ RKN } \\
\hline & & - & + & & & & & & \\
\hline \multirow[t]{2}{*}{ Cystatin C } & + & 14 & 1 & $82,4 \%$ & 85,71 & $93,33 \%$ & $66,67 \%$ & 5,76 & 0,21 \\
\hline & - & 3 & 6 & & & & & & \\
\hline
\end{tabular}


Tabel 3 Sensitivitas, Spesifisitas, Nilai Prediksi Positif (NPP), Nilai Prediksi Negatif (NPN), Rasio Kemungkinan Positif (RKP), dan Rasio Kemungkinan Negatif (RKN) Kreatinin Serum (COP 1,3 mg/dL) terhadap CGA

\begin{tabular}{|c|c|c|c|c|c|c|c|c|c|}
\hline & & \multicolumn{2}{|c|}{ CGA } & \multirow{2}{*}{ Sensitivitas } & \multirow{2}{*}{ Spesifisitas } & \multirow{2}{*}{ NPP } & \multirow{2}{*}{ NPN } & \multirow{2}{*}{ RKP } & \multirow{2}{*}{ RKN } \\
\hline & & - & + & & & & & & \\
\hline \multirow[t]{2}{*}{ Cystatin C } & + & 9 & 1 & $52,9 \%$ & $85,7 \%$ & $90 \%$ & $42,9 \%$ & 3,7 & 0,55 \\
\hline & - & 8 & 6 & & & & & & \\
\hline
\end{tabular}

kemungkinan negatif adalah 0,55.

Kreatinin serum dalam studi ini memiliki kemampuan menentukan prognosis seorang penderita yang akan mengalami cedera ginjal akut atau tidak. Hasil analisis menggunakan kurva ROC diperoleh area di bawah kurva (AUC) ROC adalah 0,785 (IK 95\%: 0-100\%; $\mathrm{p}=0,005$ ). Berdasarkan kurva sensitivitas dan spesifisitas diperoleh nilai cut-off point untuk kreatinin serum adalah 1,0 mg/L. Sensitivitas kreatinin serum dengan menggunakan cut-off point $1,0 \mathrm{mg} / \mathrm{L}$ adalah $82,4 \%$ dan spesifisitas $85,7 \%$.

Nilai prediksi positif (PPV) kreatinin serum sebesar 93,3\% dan nilai prediksi negatif (NPV) 66,7\%; sedangkan untuk rasio kemungkinan positif 5,76 dan rasio kemungkinan negatif 0,21 .

\section{Pembahasan}

Monitoring fungsi ginjal merupakan hal yang sangat penting dalam manajemen pasien sakit kritis di ruang rawat intensif. Hal tersebut menjadi penting mengingat angka kejadian CGA yang tinggi di ruang rawat intensif yang berkisar 36-67\%. ${ }^{1}$ Laju filtrasi glomerulus (LFG) yang dinilai melalui beberapa substrat atau penanda biologis menjadi parameter baku emas untuk monitoring fungsi ginjal. Penanda biologis yang ideal untuk mendiagnosis CGA harusnya terjangkau, cepat, mudah diukur, dan juga diproduksi dalam tingkat yang stabil. Hal ini dapat menentukan tingkat keparahan disfungsi, khusus untuk ginjal, meningkat di tahap awal disfungsi dengan sensitivitas dan spesifisitas yang tinggi. Sampai saat ini belum ada penanda biologis yang dapat memenuhi seluruh persyaratan menjadi penanda biologis yang ideal.

Kreatinin saat ini adalah penanda biologis yang paling sering digunakan untuk memantau fungsi ginjal karena pemeriksaannya mudah dan juga murah. Keterbatasan dan kekurangan kreatinin serum dalam mendeteksi penurunan fungsi ginjal terutama pada perubahan akut fungsi ginjal telah membuat kreatinin menjadi indikator fungsi ginjal yang kurang dapat diandalkan. Cystatin C merupakan penanda biologis yang diproduksi di dalam tubuh dalam tingkat yang konstan, tidak dipengaruhi oleh massa otot dan faktor diet, serta mengalami filtrasi secara bebas di glomerulus dan juga reabsorpsi oleh tubulus proksimal. Atas alasan ini, cystatin $\mathrm{C}$ menjadi penanda biologis baru yang menjanjikan untuk deteksi CGA lebih baik daripada kreatinin.

Berdasarkan penelitian ini, nilai sensitivitas cystatin $\mathrm{C}$ serum lebih tinggi dibanding dengan kreatinin serum, sensitivitas cystatin $\mathrm{C}$ adalah

Tabel 4 Sensitivitas, Spesifisitas, Nilai Prediksi Positif (NPP), Nilai Prediksi Negatif (NPN), Rasio Kemungkinan Positif (RKP), dan Rasio Kemungkinan Negatif (RKN) Kreatinin Serum terhadap CGA

\begin{tabular}{|c|c|c|c|c|c|c|c|c|c|}
\hline & & \multicolumn{2}{|c|}{ CGA } & \multirow{2}{*}{ Sensitivitas } & \multirow{2}{*}{ Spesifisitas } & \multirow{2}{*}{ NPP } & \multirow{2}{*}{ NPN } & \multirow{2}{*}{ RKP } & \multirow{2}{*}{ RKN } \\
\hline & & - & + & & & & & & \\
\hline Cystatin C & + & 14 & 1 & $82,4 \%$ & 85,71 & $93,33 \%$ & $66,67 \%$ & 5,76 & 0,21 \\
\hline
\end{tabular}


$82,4 \%$ dan kreatinin serum 52,9\%. Kedua penanda biologis tersebut memiliki spesifisitas yang sama, yaitu sebesar $85,7 \%$. Pemeriksaan cystatin $\mathrm{C}$ serum memiliki kemampuan yang lebih baik untuk tujuan skrining CGA. Hasil yang hampir serupa dinyatakan dalam suatu penelitian untuk mendeteksi disfungsi ginjal (LFG $<80 \mathrm{~mL} / \mathrm{min} / 1,73 \mathrm{~m}^{2}$ ), sensitivitas dan spesifisitas cystatin C sebesar $88 \%$ dan $97 \%$, sedangkan pada kreatinin $48 \%$ dan $100 \%{ }^{18}$

Laju filtrasi glomerulus pada pasien sakit kritis dapat berubah-ubah dengan cepat yang disebabkan hipoperfusi ginjal sebagai akibat syok atau sepsis. Pada fase akut perubahan LFG tersebut sering kali tidak disertai dengan peningkatan kreatinin serum karena kreatinin tersebut membutuhkan waktu untuk mencapai keadaan steady-state. Hal ini yang menjadikan keterbatasan pada kreatinin untuk mendeteksi disfungsi ginjal akut. Keadaan ini juga yang menjelaskan nilai diagnostik kreanitin yang kurang memuaskan pada penelitian ini dengan nilai AUC 0,785. Nilai diagnostik kreatinin serum yang kurang baik ini sesuai dengan beberapa penelitian lain yang mengemukakan nilai AUC kreatinin serum 0,694. ${ }^{13}$ Hal yang sama juga ditunjukkan pada suatu penelitian yang menunjukkan nilai AUC kreatinin serum sebesar $0,698 .{ }^{12}$

Dalam penelitian hasil nilai diagnostik yang baik pada cystatin $\mathrm{C}$ dalam memprediksi CGA dibanding dengan nilai creatinin clearance (LFG) urin 24 jam. Hal ini ditunjukkan dengan nilai diagnostik cystatin C dengan AUC 0,874. Hasil serupa diperlihatkan pada penelitian yang menyatakan bahwa cystatin C serum memiliki kemampuan yang lebih baik dalam mendeteksi penurunan LFG (LFG $<80 \mathrm{~mL}$ / $\min / 1,73 \mathrm{~m}^{2}$ ) dibanding dengan nilai kreatinin serum. ${ }^{7}$ Nilai diagnostik cystatin $\mathrm{C}$ yang baik dalam mendeteksi CGA juga dijumpai pada penelitian yang menunjukkan nilai AUC sebesar $0,927 .{ }^{13}$ Pada suatu hasil penelitian didapatkan bahwa cystatin $\mathrm{C}$ menunjukkan kemampuan yang juga baik dalam memperkirakan CGA pada pasien sepsis dengan nilai AUC 0,82. ${ }^{19}$ Selanjutnya, pada penelitian lain dinyatakan bahwa nilai diagnostik cystatin $\mathrm{C}$ itu sendiri kurang baik dengan AUC 0,735, tetapi cystatin
C memiliki nilai diagnostik yang lebih baik daripada kreatinin dalam mendiagnosis CGA. ${ }^{12}$

Receiver operating characteristic (ROC) penelitian ini didapatkan nilai cut-off kreatinin serum $1,0 \mathrm{mg} / \mathrm{dL}$ dan cystatin $\mathrm{C}$ serum sebesar $1,03 \mathrm{mg} / \mathrm{L}$ dengan sensitivitas dan spesifisitas yang sama sebesar $82,4 \%$ dan $85,7 \%$. Nilai cutoff yang berbeda ditunjukkan pada penelitian bahwa cystatin $\mathrm{C}$ mempunyai nilai cut-off 1,36 $\mathrm{mg} / \mathrm{L}$ dengan sensitivitas $98 \%$ dan spesifisitas 99\%, sedangkan kreatinin mempunyai cutoff point 103 mikromol/L dengan sensitivitas $80 \%$ dan spesifisitas $100 \% .{ }^{9}$ Pada penelitian lain oleh Artunc dkk. ${ }^{20}$ yang menilai disfungsi ginjal pada pasien yang menjalani kateterisasi jantung menunjukkan bahwa nilai cystatin $\mathrm{C}$ $>1,3 \mathrm{mg} / \mathrm{L}$ memberikan sensitivitas $88 \%$ dan spesifisitas 96\%. Sebagai perbandingannya, nilai cut-off point untuk kreatinin adalah 1,2 $\mathrm{mg} / \mathrm{L}$ dengan sensitivitas dan spesifisitas sebesar $63 \%$ dan $80 \%$.

Salah satu kelemahan cystatin C adalah masalah harga. Harga pemeriksaan cystatin $\mathrm{C}$ cukup mahal dibanding dengan pemeriksaan kreatinin dengan biaya hampir 5-6 kali lipat lebih tinggi. Bila kita telaah lebih lanjut bila CGA dapat dideteksi lebih awal maka kita dapat mencegah dan juga memproteksi fungsi ginjal dari perburukan lebih lanjut sehingga pasien mempunyai peluang lebih besar terhindar dari penggunaan modalitas terapi pengganti ginjal (TPG). Akhirnya, diharapkan terjadi peningkatan outcome pada pasien. Sebenarnya bila dilihat dari total biaya sebenarnya akan lebih banyak dana yang dapat dihemat bila CGA didiagnosis lebih dini. Oleh karena itu, kami sangat menganjurkan kepada fasilitas-fasilitas ruang rawat intensif agar pemeriksaan cystatin $\mathrm{C}$ sebagai alternatif penanda biologis pilihan untuk menegakkan diagnosis CGA pada pasien sakit kritis.

\section{Simpulan}

Deteksi CGA dan sepsis secara dini merupakan parameter penting pada pasien penyakit kritis yang dirawat di ruang rawat intensif. Pada penelitian ini, cystatin $\mathrm{C}$ memiliki hasil nilai diagnostik yang lebih baik dibanding dengan 
kreatinin serum sebagai penanda biologis untuk memprediksi kejadian CGA pada pasien sepsis, sepsis berat, serta syok sepsis yang dirawat di ruang rawat intensif. Pemeriksaan cystatin $\mathrm{C}$ masih jarang digunakan karena biaya relatif lebih mahal dibanding dengan pemeriksaan kreatinin serum.

Peneliti sangat mengharapkan pemeriksaan cystatin C ini dapat dipergunakan secara luas di ruang rawat intensif untuk memonitoring fungsi ginjal agar CGA dapat didiagnosis lebih dini sehingga pasien memiliki peluang yang lebih baik untuk terhindar dari penggunaan TPG.

\section{Daftar Pustaka}

1. Dennen P, Douglas IS, Anderson R. Acute kidney injury in the intensive care unit: an update and primer for the intensivist Denver. Crit Care Med. 2010;38(1):26175.

2. Uchino S, Kellum JA, Bellomo R, Doig GS, Morimatsu H, Morgera S, dkk. Acute renal failure in critical ill patients: a multinational, multicenter study. JAMA. 2006;294(7):813-8.

3. Piccinni P, Cruz DN, Gramaticopolo S, Garzotto F, Dal Santo M, Aneloni G, dkk. Prospective multicenter study on epidemiology of acute kidney injury in the ICU: a critical care nephrology Italian collaborative effort (NEFROINT). s.l. : Minerva Anestesiol. 2011;77(11):107283.

4. Kellum JA, Srisawat N. Acute kidney injurydefinition and classification. Eur Crit Care Emerg Med. 2010;5:102-6.

5. Mehta RL, Kellum JA, Shah SV, Molitoris BA, Ronco C, Warnock DG, dkk. Acute kidney injury network: acute kidney injury network: report of an initiative to improve outcomes in acute kidney injury. Crit Care. 2007;11:31.

6. Uchino S, Kellum JA, Bellomo R. Acute renal failure in critically ill patients: a multinational, multicenter study. JAMA. 2006;294:813-8.

7. Aydogdu M, Gursel G, Sancak B, Yeni S,
Sari G, Tasyurek S, dkk. The use of plasma and urine neutropil gelatinase associated lipocalin (NGAL) and cystatin C in early diagnosis of septic acute kidney injury in critically ill patients. Disease Markers. 2013;34:237-46.

8. Liangos $\mathrm{O}$, Han WK, Wald R, Perianayagam MC, Mackinnon RW, Dolan N, dkk. Urinary kidney injury molecule- 1 level is an early and sensitive marker of acute kidney injury following cardiopulmonary bypass. J Am Soc Nephrol. 2006;17:403.

9. Parikh CR, Mishra J, Thiessen-Philbrook H, Dursun B, Ma Q, Kelly C, dkk. Urinary IL-18 is an early predictive biomarker of acute kidney injury after cardiac surgery. Kidney Int. 2006;70:199-203.

10. Devarajan P. Emerging biomarkers of acute kidney injury. Dalam: Bellomo R, penyunting. Acute kidney injury. Basel: Karger AG; 2007. hlm. 203-9.

11. Dent CL, Ma Q, Dastrala S, Bennett M, Mitsnefes MM, Barasch J. Plasma neutrophil gelatinase-associated lipocalin predicts acute kidney injury, morbidity and mortality after pediatric cardiac surgery: a prospective uncontrolled cohort study. Crit Care. 2007;11:127.

12. Chung MY, Won Jun D, Sung SA. Diagnostic value of cystatin $C$ for predicting acute kidney injury in patients with liver cirrhosis. Korean J Hepatol. 2010;16:3017.

13. Molitoris BA, Melnikov VY, Okusa MD, Himmelfarb J. Technology insight: biomarker development in acute kidney injury -What can we anticipate?. Nat Clin Pract Nephrol. 2008;4:154-65.

14. Royakkers AA, Korevaar JC, Van Suijlen JD, Hofstra LS, Kuiper MA, Spronk PE, dkk. Serum and urine cystatin $C$ are poor biomarkers for acute kidney injury and renal replacement therapy. Intens Care Med. 2011;37:493-501.

15. Spahillari A, Parikh CR, Sint K, Koyner JL, Patel UD, Edelstein CL, dkk. Serum cystatin C- versus creatinine-based definitions of acute kidney injury following cardiac surgery: a prospective cohort study. Am J 
Kidneys Dis. 2012;60:922-9.

16. Slort PR, Ozden N, Pape L, Offner G, Tromp WF, Wilhelm AJ, dkk. Comparing cystatin C and creatinine in the diagnosis of pediatric acute renal allograft dysfunction. Pediatr Nephrol. 2012;27:843-9.

17. Doi K, Peter ST, Eisner C, Hu X, Leelahavanichkul A, Schnermann J, dkk. Reduced production of creatinine limits its use as a marker of kidney injury in sepsis. J Am Soc Nephrol. 2009;20:1217-21.

18. Vaidya VS, Ferguson MA, Bonventre JV.
Biomarkers of acute kidney injury. Ann Rev Pharmacol Toxicol. 2008;48:463-93.

19. Grootaert V, Willems L, Debaveye Y, Meyfroidt G, Spriet I. Augmented renal clearance in the critically ill: how to assess kidney function. Ann Pharmacother. 2012; 46(7-8):952-9.

20. Artunc FH, Fischer IU, Risler T, Erley CM. Improved estimation of GFR by serum cystatin $\mathrm{C}$ in patients undergoing cardiac catheterization. Int J Cardiol 2005;102:173-8. 